\title{
Use of proton pump inhibitors in dialysis unit in tertiary care hospital: a pharmaco-epidemiological study
}

\author{
Shabbir R. Pendhari ${ }^{1}$, Kedar S. Joshi², Ramchandra P. Limaye ${ }^{1 *}$
}

\author{
${ }^{1}$ Bharati Vidyapeeth (Deemed to be University) Medical College and Hospital, Sangli, Maharashtra, India \\ ${ }^{2}$ Haul Medizin Pvt Ltd, Pune, Maharashtra, India
}

Received: 27 March 2021

Revised: 04 May 2021

Accepted: 13 May 2021

\section{*Correspondence:}

Dr. Ramchandra P. Limaye,

Email: rplimaye@gmail.com

Copyright: (C) the author(s), publisher and licensee Medip Academy. This is an open-access article distributed under the terms of the Creative Commons Attribution Non-Commercial License, which permits unrestricted non-commercial use, distribution, and reproduction in any medium, provided the original work is properly cited.

\begin{abstract}
Background: Proton pump inhibitors (PPI) are generally thought to be safer drug with fewer adverse effects. Though this class of the drug is thought to be well tolerated, a detail study about actual use of these agents in nephrology department is still awaited in many parts of India. There had been case reports and case series which were reporting PPIs producing acute interstitial nephritis progressing to acute renal failure. The risk of PPI treatment in haemodialysis patients remains unexplored. The aim of the study was to evaluate a drug utilization of PPI in patient undergoing haemodialysis procedure.

Methods: In this study every day visit to the dialysis units of the hospitals was carried out. After taking consent from the patients, the information from the case-report form was noted like; age, sex, diagnosis, laboratory reports and drug prescried. No personally identifiable information about patient or physician was collected. After this an interview of patients was taken.

Results: In this study, out of 126 patients $76.6 \%$ were male and $23.4 \%$ were female. Out of these 126 patients $88.89 \%$ patients were on PPI. Nearly $54 \%$ were using PPI for more than six months. Nearly $29 \%$ patients were using PPI for more than 12 months.

Conclusions: As many case-reports and studies are suggesting, there is co-relation of PPI and acute interstitial nephritis from this study we suggest that especially in nephrology unit patients', more caution must be exercised while using PPI.
\end{abstract}

Keywords: PPI, Drug utilization study, Dialysis, AIN, ARF

\section{INTRODUCTION}

The principal aim of drug utilization research is to facilitate the rational use of drugs in populations. Without knowledge of how drugs are being prescribed and used, it is difficult to point out or make comment on rational drug use or to suggest measures to improve prescribing habits. Though drug utilization research in itself does not necessarily provide answers, but it contributes to rational drug use in important ways as how drugs are being used like, (prevalence, incidence, extent of use) at a particular moment and/or in a particular area (eg. in a country, region, community or hospital). Researchers can evaluate as what extent of drugs (properly used, overused or underused), the pattern or profile of drug use, and can compare the observed patterns of drug use (for the treatment of a certain disease with current recommendations or guidelines). ${ }^{1}$

Proton pump inhibitors (PPIs) are generally well tolerated. PPI generally thought to be safer drug with fewer adverse effects, which are similar to the placebo with less than 5\% incidence ratio, so PPIs are the most commonly used drug worldwide. ${ }^{2}$ Several drug utilization studies were carried out in India, which show that the use of proton pump inhibitors varies from $45-85 \%$ in different conditions. ${ }^{3-7}$ In $82.96 \%$ of patients suffering from chronic renal disease PPI were used. $^{8}$ Another study of intravenous PPI 
utilization shows in $89 \%$ internal medicine ward patients and $34.04 \%$ patients in surgery ward PPI were used. ${ }^{9}$

Though this class of the drug is thought to be well tolerated there had been case reports and case series which were reporting PPIs producing acute interstitial nephritis (AIN) progressing to acute renal failure (ARF). The first report of omeprazole induced AIN was reported in 1992 while that of pantoprazole and lansoprazole were reported on 2004, simultaneously similar reports of all PPI are coming. ${ }^{10}$ The risk of PPI treatment in hemodialysis patients remains unexplored. ${ }^{\mathbf{1 1}}$ The aim of the study was to evaluate drug utilization of PPI in patient undergoing haemodialysis procedure.

\section{METHODS}

This observational study was conducted in the dialysis units of Bharati Vidyapeeth (Deemed to be University) Medical College and Hospital, Sangli and Government Medical College, Miraj. Study was conducted from $1^{\text {st }}$ January 2015 to $31^{\text {st }}$ March 2015. The patient undergoing dialysis and giving consent to involve in the study such patients were selected. After taking consent from the patients, the information from the case-report form was noted like; age, sex, diagnosis, laboratory reports. No personally identifiable information about patient or physician was collected. Along with this information, the patient's prescription was also noted from case report form. After this an interview was taken by asking following questions to the patient- (a) when the dialysis process done first? (b) how many times you have gone through this procedure of dialysis? (c) after how many days you have to do another procedure of dialysis (d) which drugs you take before, during and after the procedure of dialysis? (e) if the prescription contains any PPI then, from how many days you are taking these drugs continuously? (f) in between two different dialysis procedures do you suffer from any gastritis or GIT related problems? If yes, which drug you take to get relief from that.

\section{RESULTS}

The average age of patients was $47.04 \pm 14.75$ (mean \pm SD) (range 19-77 years). In this study we observed that out of 126 patients $76.6 \%$ were male and $23.4 \%$ were female. Out of these 126 patients $88.89 \%$ patients were on PPI (Table 1).

Only $3 \%$ patients were on NSAIDs and paracetamol was the commonest used NSAID. $11.11 \%$ prescriptions contained antimicrobial agents; in this amoxicillin in combination with clavulanic acid was the most commonly used combination. Nearly $33.33 \%$ patients were using FDC of PPI out of which domperidone+PPI was the commonest used FDC (Figure 1).

We observed that nearly $54 \%$ patients in dialysis unit were using PPI for more than last six months. While 35\% patients taking PPI from last 1 to 6 months. Nearly $29 \%$ patients were taking PPI for more than 12 months. Out of these, 2 patients each took PPI for more than 30 months and 42 months. It ranges from 1-43 months. Most of the patients from study group were undergoing dialysis for twice a week. It was good to note that $98 \%$ patients did not consume any OTC drug without physicians' advice. Amongst all these patients $16 \%$ patients were newly diagnosed, and they had undergone the dialysis procedure less than 10 times. $12 \%$ patients had done dialysis in between 51-60 times. One of them had it done for 1040 times (Figure 3).

Table 1: Demographic data

\begin{tabular}{|lllll|}
\hline $\begin{array}{l}\text { Age } \\
\text { group } \\
\text { (years) }\end{array}$ & Total & Male & Female & $\begin{array}{l}\text { Percentage } \\
(\%)\end{array}$ \\
\hline $\mathbf{1 1 - 2 0}$ & 5 & 3 & 2 & 3.55 \\
\hline $\mathbf{2 1 - 3 0}$ & 21 & 17 & 4 & 14.89 \\
\hline $\mathbf{3 1 - 4 0}$ & 26 & 18 & 8 & 18.44 \\
\hline $\mathbf{4 1 - 5 0}$ & 28 & 23 & 5 & 19.86 \\
\hline $\mathbf{5 1 - 6 0}$ & 34 & 26 & 8 & 24.11 \\
\hline $\mathbf{6 1 - 7 0}$ & 24 & 19 & 5 & 17.02 \\
\hline $\mathbf{7 1 - 8 0}$ & 3 & 2 & 2 & 2.13 \\
\hline Total & 141 & 108 & 33 & 100.00 \\
\hline
\end{tabular}

Table 2: Frequency of dialysis.

\begin{tabular}{|lll|}
\hline $\begin{array}{l}\text { Duration in between two } \\
\text { dialysis }\end{array}$ & $\begin{array}{l}\text { No. of } \\
\text { patients }\end{array}$ & $\begin{array}{l}\text { Percentage } \\
(\%)\end{array}$ \\
\hline One per week & 01 & 0.79 \\
\hline Two per week & 124 & 98.41 \\
\hline $\begin{array}{l}\text { One per week for one year } \\
\text { than two per week }\end{array}$ & 01 & 0.79 \\
\hline Total & 126 & 100.00 \\
\hline
\end{tabular}

Table 3: Number of patients having dialysis for less than year.

\begin{tabular}{|lll|}
$\begin{array}{l}\text { Duration on dialysis } \\
\text { (months) }\end{array}$ & $\begin{array}{l}\text { No. of } \\
\text { patients }\end{array}$ & $\begin{array}{l}\text { Percentage } \\
(\%)\end{array}$ \\
\hline $\mathbf{0 - 1}$ & 17 & 13.49 \\
\hline $\mathbf{1 - 2}$ & 10 & 7.94 \\
\hline $\mathbf{2 - 3}$ & 08 & 6.35 \\
\hline $\mathbf{3 - 4}$ & 05 & 3.97 \\
\hline $\mathbf{4 - 5}$ & 03 & 2.38 \\
\hline $\mathbf{5 - 6}$ & 06 & 4.76 \\
\hline $\mathbf{6 - 7}$ & 08 & 6.35 \\
\hline $\mathbf{7 - 8}$ & 08 & 6.35 \\
\hline $\mathbf{8 - 9}$ & 05 & 3.97 \\
\hline $\mathbf{9 - 1 0}$ & 04 & 3.17 \\
\hline $\mathbf{1 0 - 1 1}$ & 04 & 3.17 \\
\hline $\mathbf{1 1 - 1 2}$ & 10 & 7.94 \\
\hline Total & 88 & 69.84 \\
\hline
\end{tabular}


Table 4: OTC PPI consumption by dialysis unit patients.

\begin{tabular}{|lll|}
\hline $\begin{array}{l}\text { OTC } \\
\text { consumption } \\
\text { of PPI }\end{array}$ & No. of patients & $\begin{array}{l}\text { Percentage } \\
(\%)\end{array}$ \\
\hline No & 123 & 97.62 \\
\hline & 03 & \multirow{2}{*}{2.38} \\
\cline { 2 - 2 } Yes & $\begin{array}{l}\text { Ranitidine }=01 \\
\text { Omeprazole }=01\end{array}$ \\
\cline { 2 - 2 } & $\begin{array}{l}\text { Ranitidine+ } \\
\text { omeprazole }=01\end{array}$ \\
\hline Total & 126 & 100 \\
\hline
\end{tabular}

Table 5: Use of PPI in patient having dialysis more than 200 time.

\begin{tabular}{|l|l|}
\hline $\begin{array}{l}\text { No. of dialysis for more } \\
\text { than 200 times }\end{array}$ & $\begin{array}{l}\text { Duration of PPI } \\
\text { months }\end{array}$ \\
\hline $\mathbf{2 0 8}$ & 24 \\
\hline $\mathbf{2 1 6}$ & 37 \\
\hline $\mathbf{2 2 4}$ & $>3$ \\
\hline $\mathbf{2 2 4}$ & 25 \\
\hline $\mathbf{2 2 4}$ & 26 \\
\hline $\mathbf{2 4 2}$ & $>6$ \\
\hline $\mathbf{2 5 0}$ & $>18$ \\
\hline $\mathbf{2 6 0}$ & $>27$ \\
\hline $\mathbf{2 7 0}$ & 6 \\
\hline $\mathbf{2 7 0}$ & 43 \\
\hline $\mathbf{3 1 2}$ & $>6$ \\
\hline $\mathbf{3 3 8}$ & $>12$ \\
\hline $\mathbf{3 6 4}$ & $>12$ \\
\hline $\mathbf{3 7 4}$ & 43 \\
\hline $\mathbf{9 3 6}$ & $>36$ \\
\hline $\mathbf{1 0 4 0}$ & $>24$ \\
\hline
\end{tabular}

Table 6: Use of PPI in patient having dialysis less than 10 times.

\begin{tabular}{|l|l|}
$\begin{array}{l}\text { No. of dialysis for less than } \\
\mathbf{1 0} \text { times }\end{array}$ & $\begin{array}{l}\text { Duration of PPI } \\
\text { months }\end{array}$ \\
\hline $\mathbf{3}$ & 10 days \\
\hline $\mathbf{4}$ & 15 days \\
\hline $\mathbf{4}$ & 2 \\
\hline $\mathbf{4}$ & 2 \\
\hline $\mathbf{5}$ & 1 \\
\hline $\mathbf{6}$ & 20 days \\
\hline $\mathbf{6}$ & 2 \\
\hline $\mathbf{8}$ & 15 days \\
\hline $\mathbf{8}$ & 1 \\
\hline $\mathbf{8}$ & 1 \\
\hline $\mathbf{8}$ & 1 \\
\hline $\mathbf{8}$ & 1 \\
\hline $\mathbf{8}$ & 2 \\
\hline $\mathbf{9}$ & 1 \\
\hline $\mathbf{9}$ & 3 \\
\hline
\end{tabular}

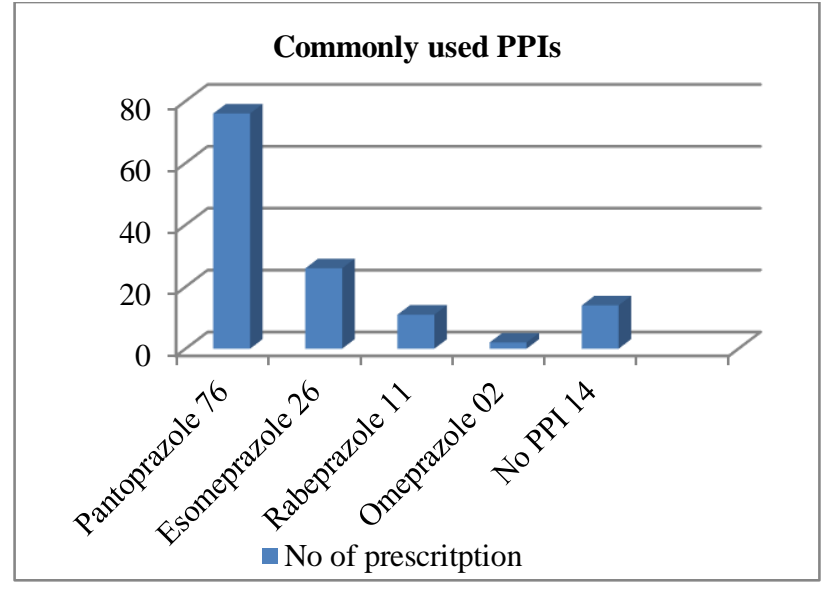

Figure 1: Commonly used PPIS.

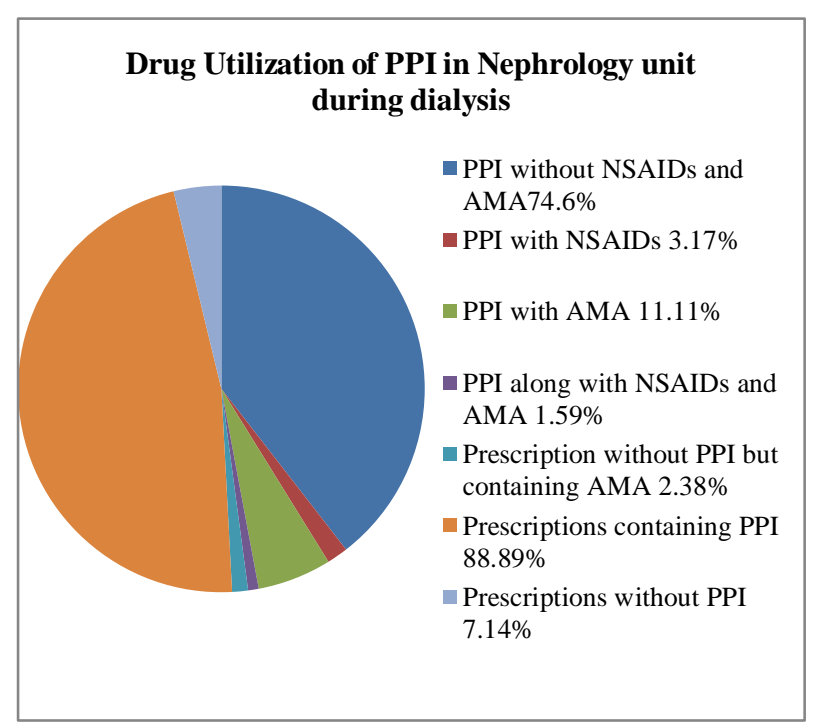

Figure 2: Utilization of PPI in dialysis patients.

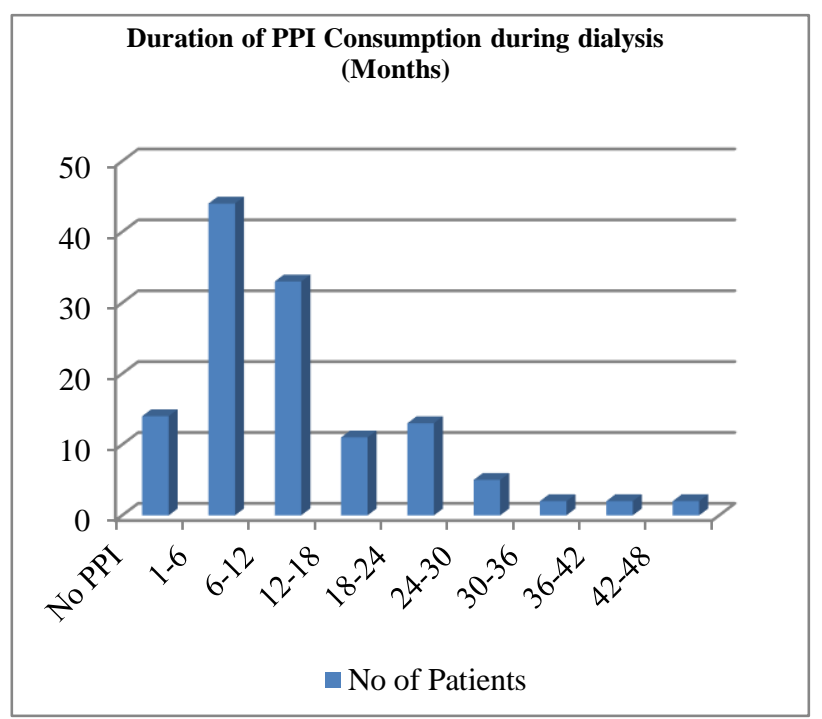

Figure 3: Duration of PPI consumption during dialysis. 


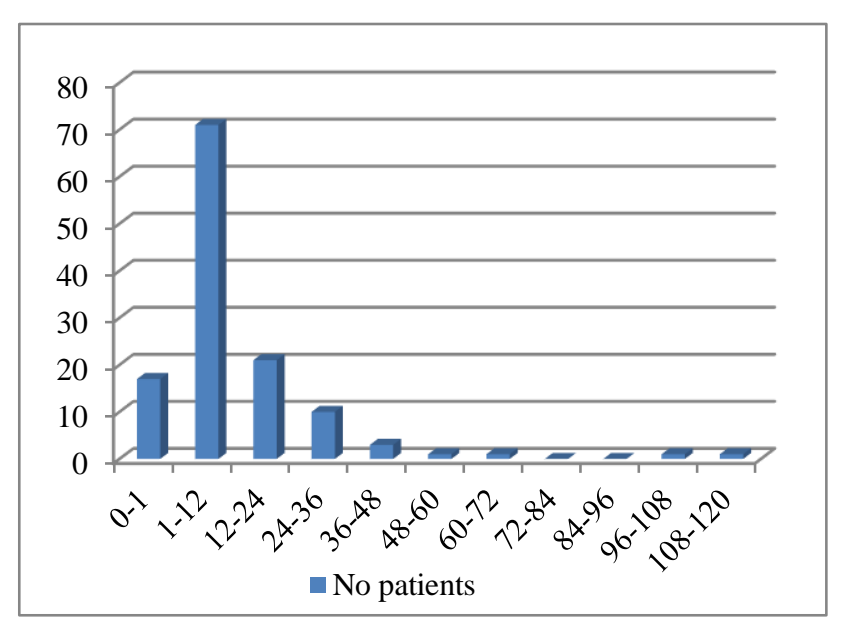

Figure 4: Duration of dialysis in months.

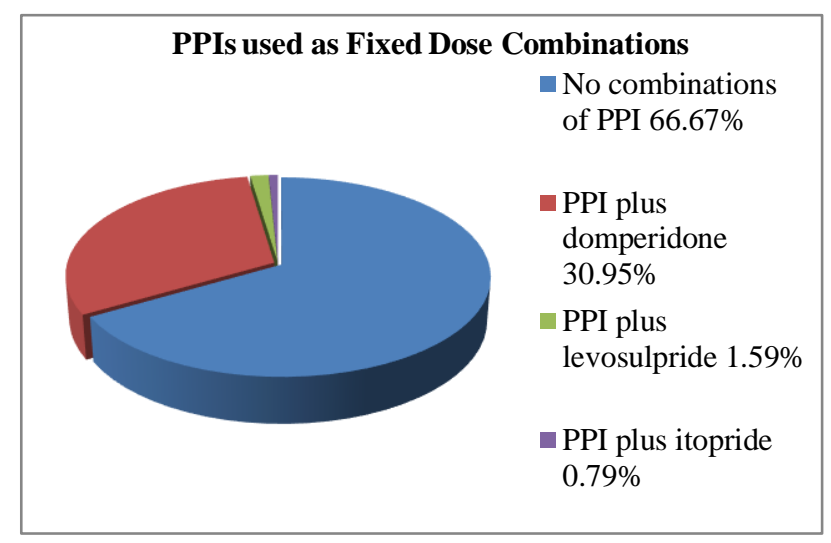

Figure 5: PPIS as fixed dose combinations.

\section{DISCUSSION}

Chronic renal failure is a worldwide public health problem, there is still increase in incidence and prevalence observed because of co-morbidities resulting in polypharmacy. So, we had planned drug utilization of PPI in patient undergoing dialysis procedure in the nephrology department. We wanted to know, if there is positive corelation between PPI and AIN, then what is the burden of PPI in 'nephro-compramised' patients.

Our study shows nearly $89 \%$ burden of PPI in study population. (Figure 1)

A study by Tamilselvan et al observed $82.96 \%$ patients who were treated for CKD were on PPI. ${ }^{8}$ This is nearly equal to our study. But a study done by Soumya Santra et al observed $98 \%$ patients with CKD were on antiulcer agents like PPI and $\mathrm{H} 2$ blockers, but they fail to explain the distribution of these two classes. ${ }^{12}$ Angel et al observed that $79.2 \%$ patients were on PPI in haemodialysis patients. ${ }^{11}$ Another study was done by Misra et al and Erdem et al done a study to find out relation of PPI with serum magnesium in haemodialysis patients where they observed $55 \%$ and $72 \%$ patients were on PPI respectively. ${ }^{13,14}$
Only $3 \%$ patients were on NSAIDs and paracetamol was the commonest used NSAID. $11.11 \%$ prescriptions contained antimicrobial agents, in this amoxicillin in combination with clavulanic acid was the most commonly used combination (Figure 2). It is nearly similar to Lee et al who observed $7.1 \%$ patients with CKD stage 3-4 and $6.6 \%$ pts with CKD-5 end stage renal diseases ware using NSAIDs. ${ }^{15}$ Santra et al also found that $58 \%$ patients were on AMA while $30 \%$ patients were on NSAIDs, this is very high as compared with our study. But there are very less studies on the drug utilization in chronic kidney disease patients. $^{12}$

In this study we asked five questions regarding use of PPI, we observed that nearly $54 \%$ patients in dialysis unit were using PPI for more than last six months. While $35 \%$ patients taking PPI from last 1 to 6 months. Nearly $29 \%$ patients were taking PPI for more than 12 months. Out of these, 2 patients each took PPI for more than 30 months and 42 months. It ranges from 1-43 months. (Table 5)

Such kind of findings were observed in study of Misra et al where patients consume PPI for 4 to 25 months. ${ }^{13}$ In study done by Lee et al observed that CKD patients are taking PPI for a much longer duration compared to nonCKD patients (range 63-273 days vs 56-176 days respectively). ${ }^{15}$ In another study of Erdem et al patients with haemodialysis were using PPIs for average of 42.5 \pm 35 months (range 3-144 months) which is very high. $^{14}$ But it may be harmful because by the Sampathkumar et al the average age of PPI induced AIN was $52.5 \pm 18$ years while duration of PPI consumption before diagnosis of AIN was 1-8 weeks. ${ }^{16}$ In other study of Ray et al in patients diagnosed with PPI induced AIN the age varied from 61-87 and duration of PPI varied from 10 days to 26 months. ${ }^{17}$ In these two examples we have to think about one point that, in both studies one patient had developed PPI induced AIN within 10 day of PPI use.

Most of the patients from study group were undergoing dialysis for twice a week (Table 3). Nearly $98 \%$ patients did not consume any OTC drug without physicians advice. (Table 4)

Nearly $16 \%$ patients were newly diagnosed, and they had undergone the dialysis procedure less than 10 times. $12 \%$ patients had done dialysis in between 51-60 times. There was one patient who had done this procedure for more than 1040 times. It is also observed that in patients having multiple dialysis sessions PPI were still in use in large extent. (Table 4, 5)

When we think about the duration of months of dialysis, we observed that nearly $70 \%$ patients started this therapy one year (12 months) before. While 30\% patients were following this therapy for more than 12 months. There was one patient who had been undergoing dialysis for nearly 10 years (Figure 4 ). 
Nearly $33.33 \%$ patients were using FDC of PPI out of which domperidone+PPI was the commonest used FDC (Figure 5).

After comparing the use of PPI and PPI co-prescribed AMA and NSAIDS in drug utilization studies we found that, since patients undergoing dialysis are known to suffer from hyperacidity, gastric problem and symptoms like heart burn due to multiple causes, including the underlying disease process which had mandated dialysis. Hence statistically significant use of PPI was expected. We have received similar results in our nephrology unit. This is similar to the study of Tamilselvan et al and Santraet al. ${ }^{12}$

Our earlier experimental study had postulated a possible connection between use of PPI and AIN. ${ }^{18}$ Based on such similar studies and other reports FDA has included this statement in his latest report in view of this information extensive use of PPI in dialysis patients is a potential problem in the nephrology unit. Multicentric as well as continuous follow-up studies might be needed before conclusive guidelines for contraindications are formed.

\section{CONCLUSION}

As PPIs follow hepatic metabolism and no dose modification is required in patients with kidney disease, the use of PPI will be observed more. But as many case reports and studies are reports suggesting, we also found that there is probable co-relation of PPI and higher number of dialysis session. Acute interstitial nephritis can be a contributing factor for this observation (as experimental study have demonstrated such effect). We suggest that especially in nephrology unit patients, more caution must be exercised while using PPI.

Funding: No funding sources

Conflict of interest: None declared

Ethical approval: The study was approved by the Institutional Ethics Committee

\section{REFERENCES}

1. WHO. Introduction to drug utilization research. What is drug utilization research and why is it needed? Geneva: WHO; 2003: 8-12.

2. Vanderhoff BT, Tahboub RM. Proton pump inhibitors: an update. Am Fam Physician. 2002;66(2):273-80.

3. Raghvendra B, Sanji N, Ullal SD, Kamath R, Pain MRSM, Kamath $\mathrm{S}$, et al. Trends in prescribing gastroprotective agents with non-steroidal antiinflammatory drugs in an orthopedic outpatient unit of a tertiary care hospital. J clin daog research. 2009;3:1553-6.

4. Nouseen, Tadvi NA, Shareef SM. Use of proton pump inhibitors ingeneral practice. is it rationale?. Int J Med Res Health Sci.2014;3;1:37-42.
5. Kaur S, Rajagopalan S, Kaur N, Shafiq N, Bhalla A, Pandhi P, Malhotra S. Drug utilization study in medical emergency unit of a tertiary care hospital in North India. Emerg Med Int. 2014;973578.

6. Barot PA, Malhotra SD, Rana DA, Patel VJ, Patel KP. Drug utilization in emergency medicine department at a tertiary care teaching hospital: A prospective study. J Basic Clin Pharm. 2013;4(4):78-81.

7. Pravinkumar L, Prakash HP, Vibhavari L. Study of rational prescribing and dispensing of preparations with nonsteroidal anti-inflammatory drugs in orthopedic outpatient department. Asian J Pharm Clin Res. 2015;4;4:278-81.

8. Tamilselvan T, Veerapandiyan AK, Karthik N. Study on drug utilization pattern of chronic renal failure patient in a tertiary care hospital. Int J Pharm Sci. 2014;6;9:482-84.

9. Churi S, Jogani A. Prospective assessment of prescribing pattern of intravenous proton pump inhibitors in an Indian tertiary care teaching hospital. Indian J Pharma Practice. 2004;7(4):2-7.

10. Geevasinga N, Patrik LC, Angela CW, Simon DR. Proton pump inhibitors and acute interstitial nephritis. Clin Gastro Hep. 2006;4:597-604.

11. Francisco ALM, Varas J, Ramos R, Merello JI, Canaud B, Stuard S, Pascual J, et al. Proton Pump Inhibitor Usage and the Risk of Mortality in Hemodialysis Patients. Kidney Int Rep. 2017;3(2):374-84.

12. Santra S, Agrawal D, Kumar S, Mishra SS. A study on the drug utilization pattern in patients with chronic kidney disease with emphasis on antibiotics. J Integr Nephrol role. 2015;2(3):85-9.

13. Misra PS, Alam A, Lipman ML, Nessium SJ. The relationship between proton pump inhibitor use and serum magnesium concentration among hemodialysis patients: a cross sectional study. BMC Nephrol. 2015;16:136-40.

14. Erdem E. Proton pump inhibitors use in hemodialysis patients and serum magnesium levels. Int J Clin Exp Med. 2015;8(11):21689-93.

15. Lee HJ, Lee H, Oh SH, Park J, Park S, Jeon JS, Noh H, Han DC, Kwon SH. Chronic kidney disease (CKD) patients are exposed to more proton pump inhibitor (PPI)s compared to non-CKD patients. PLoS One. 2018;13(9):203878.

16. Sampathkumar K, Ramlingam R, Prabhakar A, Abraham A. Acute interstitial nephritis due to proton pump inhibitors. Ind J Nephro. 2013;23(4):304-7.

17. Ray S, Delaney M, Mullar AF. Proton pump inhibitors and acute interstitial nephritis. BMJ. 2010;34:668-70.

18. Limaye RP, Pendhari SR, Joshi KS. Proton pump inhibitors: are they safe on kidneys: a histopathological study. Int J Basic Clin Pharmacol. 2016;5:1187-92.

Cite this article as: Pendhari SR, Joshi KS, Limaye RP. Use of proton pump inhibitors in dialysis unit in tertiary care hospital: a pharmaco-epidemiological study. Int J Basic Clin Pharmacol 2021;10:643-7. 